\title{
Instructional Supports for Students with Special Education Needs in French as a Second Language Education: A Review of Canadian Empirical Literature
}

\author{
Callie Mady ${ }^{1} \&$ Stefanie Muhling ${ }^{2}$ \\ ${ }^{1}$ Schulich School of Education, Nipissing University, North Bay, Canada \\ ${ }^{2}$ Ontario Institute for Studies in Education, University of Toronto, Toronto, Canada \\ Correspondence: Callie Mady, Schulich School of Education, Nipissing University, North Bay, Canada. E-mail: \\ calliem@nipissingu.ca
}

Received: February 8, 2017

Accepted: February 26, 2017

Online Published: March 7, 2017

doi:10.5539/jel.v6n3p14

URL: http://doi.org/10.5539/jel.v6n3p14

\begin{abstract}
With the view to responding to a call for information on instructional supports for students with special education needs (SSEN) in French as a second language (FSL) education, this article reviews the empirical literature from three Canadian contexts: core French, intensive French and French immersion. More specifically, we developed this literature review by conducting an electronic search for pertinent Canadian empirical studies and manually searching select Canadian journals from the last 15 years. Our findings revealed a variety of existing instructional supports to enhance the success of SSEN in FSL programs in general and strategies for identification and intervention in French immersion in particular.
\end{abstract}

Keywords: French as a second language education, inclusion in French as a second language education, special education and second language education

\section{Introduction}

French as a second language (FSL) teachers in Canada have indicated the need for support as they endeavor to make their practice (i.e., the act of teaching) more inclusive of students with special education needs (Note 1) (SSEN). In fact, such an effort has gained in momentum in the last decade (Arnett, 2013) where inclusion of SSEN in FSL had been a question of great debate in the past (e.g., Bruck, 1978; Mannavarayan, 2002; Trites \& Price, 1976, 1977). FSL teachers, however, have indicated a need for professional development opportunities to better meet the needs of SSEN. In a national survey of over 2000 FSL teachers (Lapkin, MacFarlane, \& Vandergrift, 2006), they revealed that student diversity was their greatest challenge and suggested that provision of information and local professional development opportunities would support them to better meet students' diverse needs. Similarly, on a national level, FSL stakeholders including administrators and teachers, indicated by way of focus groups, that integration of SSEN was a primary concern (Canadian Association of Second Language Teachers, 2004). In addition to such national need, such a focused desire for professional development has been echoed provincially in Ontario (Mollica, Phillips, \& Smith, 2005) and British Columbia (Carr, 2007), for example. In their survey of over 1500 Ontario FSL teachers, Mollica, Phillips and Smith revealed a lack of confidence in their ability to meet the needs of SSEN. The over 600 FSL teachers in Carr's (2007) survey indicated a need for ongoing support to better serve their students. In response to the need expressed by FSL teachers, the Ontario Ministry of Education commissioned the more detailed literature review, on which this paper is founded, as a basis for a supporting document for FSL teachers (Ontario Ministry of Education, 2015). This outlining of research within a practical discussion document is one means of striving to have research inform practice.

Though they are willing to consider research to improve practice, Canadian FSL teachers who participated in a national survey, revealed challenges in accessing research (Mady, 2013). Through their participation in a discussion forum created to provide FSL teachers access to applied second language research and researchers, the FSL teacher participants completed an accompanying survey where they indicated that the topics of research articles are neither pertinent to their practice nor transferable to their teaching context. Despite such misgivings, the majority of FSL teacher respondents remained willing to consider research findings to inform their practice. 
In fact, when provided with relevant research articles the FSL teachers accessed them and considered their findings as possible influences on their practice (Mady, 2012). Therefore, this paper addresses a topic that FSL teachers have identified as important and highlights findings that can be applied to the FSL teaching context and beyond. Whereas in the past SSEN were at times exempt from FSL study, this literature review presents research on the inclusion of SSEN conducted over the past fifteen years where instructional supports (i.e., adaptations to teaching methods chosen to support SSEN) or SSEN in FSL were provided. Our approach to the literature supports educators in their endeavour to inform practice and access practical applications provided in research and responds to the call for more inclusive FSL education.

\section{Methodology}

To investigate the theme of instructional supports for SSEN in FSL, we followed a systematic process for document analysis following four steps (Bowen, 2009). First, we sought to find articles on the topic of SSEN in FSL. To do so, we identified core French, French immersion, intensive French (Note 2), and FSL as keywords. We then linked these key words to each of the following four subject areas: special education, gifted, learning disabilities, and exceptionalities, thereby giving a total of 16 search topics. Using these sixteen key terms, in both English and French, we conducted an electronic search for Canadian empirical studies from the last 15 years using several databases including ERIC, Education Full Text, Thesis Canada Portal and Proquest $\mathbb{R}$ Educational Journals and Dissertations. We also did a manual search of the Canadian Modern Language Review, the Canadian Journal of Applied Linguistics, and the Canadian Journal of Education. Second, we chose the articles by scanning them and selecting when pertinent to the topic of SSEN in FSL. The remaining steps involved an analysis of 42 articles as selected: 40 in English and two in French. Third, we appraised the selected articles by highlighting pertinent information (Corbin \& Strauss, 2008) and summarizing the information. Fourth, we synthesized the data according to themes, using content analysis (Labuschagne, 2003). This analysis involved a rereading of the documents with additional highlighting. We then coded the selected data and formed categories (Fereday \& Muir-Cochrane, 2006). Two experts in the field of FSL education then provided feedback on a draft of the literature review. It is important to note that this is not an exhaustive review and although additional publications are noteworthy as they pertain to the inclusion of SSEN in FSL (e.g., Bourgoin, 2014a; Wise, 2011), only articles that offered practical suggestions for the classroom teacher were considered. Table 1 presents an overview of the 42 articles, their FSL context and dominant research paradigm.

Table 1. The Corpus

\begin{tabular}{lll}
\hline Document Type & FSL Context & Dominant Research Paradigm \\
\hline Peer-reviewed articles $(N=29)$ & core French $(n=4)$ & Quantitative $(n=10)$ \\
& French immersion $(n=22)$ & Qualitative $(n=18)$ \\
& intensive French $(n=2)$ & Mixed Methods $(n=1)$ \\
& $1+\operatorname{context}(n=1)$ & \\
Chapter in Edited Books $(N=4)$ & French immersion $(n=3)$ & Qualitative $(N=4)$ \\
& $1+$ context $(n=1)$ & \\
Professional Article $(N=6)$ & French immersion $(n=4)$ & Qualitative $(n=5)$ \\
& $1+\operatorname{context}(n=2)$ & Quantitative $(n=1)$ \\
Academic Paper Presentation $(N=1)$ & French immersion $(N=1)$ & Quantitative $(N=1)$ \\
Thesis $(N=2)$ & French immersion $(N=2)$ & Qualitative $(1)$ \\
& & Quantitative $(1)$ \\
\hline
\end{tabular}

\section{Findings}

There are three FSL programs offered across Canada: core French, intensive French and French immersion. In order to highlight research pertinent to particular contexts, we have organized the findings according to the three FSL program areas. 


\subsection{Instructional Support in the Core and Intensive French Classrooms}

Within the realm of FSL research, research in the core French context is limited. As it pertains to instructional supports for SSEN in particular, to our knowledge, research in the Canadian context is limited to the work of Arnett. Arnett's (2003) observational study explored the strategies used by an FSL teacher with a Grade 9 applied core French class. In the observed class, eight of the 28 students were diagnosed with a learning disability. Through a combination of classroom observations and interviews with the teacher, Arnett determined the various strategies used by the teacher to help students better listen, speak, read and write in French and to foster an inclusive learning environment in general. Among the numerous strategies mentioned, the predominant ones were judicious use of English to clarify points, reminding students of the time remaining to complete an activity, minimizing distractions and providing positive reinforcement. The teacher also offered adaptations to her students such as the provision of additional time to complete assignments and oral instructions to accompany written instructions.

Arnett (2008) continued to explore inclusion in FSL by focusing on the point of view of the students. She interviewed students to explore the characteristics of an inclusive FSL classroom. More specifically, Arnett examined seven Grade 8 core French students' perspectives through individual interviews and one focus group interview with the seven participants with diverse needs. The interviews focused on effective/ineffective teaching practices. Through the interviews, Arnett determined that good classroom management was deemed an effective means to provide for success in FSL. In addition, students identified the use of gestures to facilitate comprehension as a strategy that promoted their success. Arnett highlighted that the teacher's familiarity with the students aided in her planning to meet individual student needs. Furthermore, Arnett noted several strategies mentioned in a study by Gersten and Baker (2000) that could be incorporated in order to aid SSEN to succeed in FSL classroom environments. These strategies include developing student vocabulary, using visual supports for tasks, using the student's first language (L1) when necessary and ensuring a balance between linguistic and cognitive demands.

In a more recent paper, Arnett (2010) explored how to effectively include all students and meet their diverse needs in the FSL classroom. Through individual interviews with the teacher and students, a focus group interview, observations and document analysis with a Grade 8 core French class, Arnett determined that a teacher's use of the target language, as well as the provision of appropriate resources was essential to student success. More specifically, she determined that the teacher's consistent use of French contributed to many students' successful learning experience. Arnett discovered that the incorporation and availability of appropriate resources in the classroom was essential to student success. Among the instructional supports Arnett identified to ensure inclusion in the classroom were: group work, using both auditory and visual aids when presenting new topics, monitoring student comprehension by asking questions and being aware of students needs. These strategies helped students to understand content and allowed for adaptation. The teacher frequently provided models and sentence starters to assist students. She worked on building language comprehension by teaching vocabulary; in one example, she had students compile a list of helpful verbs to write about a class trip. Arnett pointed out that the scaffolds the teacher used in this study were similar to those often recommended in studies on how to create a more effective second language (L2) classroom.

The intensive French program is a fairly recent program (Note 3) and thus has limited research concentrating on the specific topic of SSEN. Two studies conducted in intensive French address the inclusion of SSEN. First, Netten and Germain (2009) measured the oral proficiency of students in core French, intensive French and post-intensive French to determine their ability to communicate spontaneously in French. Although specific data concerning students with learning difficulties were not provided, the authors indicated that classes with a large number of students with learning difficulties were able to attain success in intensive French. Netten and Germain hypothesized that the success of those classes was due to teachers delivering the intensive French program through their recommended strategies: modeling of language structures, situational use and reuse of structures, use of complete sentences, and consistent corrections.

Second, Joy and Murphy's (2012) research examined the inclusion of SSEN in the intensive French program. The researchers investigated eight different Grade 6 classrooms, in which a total of 31 students were identified as having special education needs. Joy and Murphy collected data through interviews with the eight classroom teachers, four special education support teachers, three guidance counsellors, and four administrators. The authors found that SSEN in the intensive French program were integrated into class communities united by the common goal to speak French, despite the challenges they faced due to gaps in their education in the past and related lower self-esteem. The interviews linked better inclusion of SEN to the teachers' use of: a set routine, 
modeling, scaffolding, repetition, group work, music, role-playing, and a token incentive program. Though intensive French programs are now found across Canada, the research on the program and its outcomes are based in Newfoundland \& Labrador and/or connected to the developers. To fully assess the program and how it supports students with SSEN, research studies in other contexts with diverse methodologies would be of great benefit.

\subsection{Supports in French Immersion}

As with FSL research in general, FSL research examining the inclusion of SSEN is more prevalent in the French immersion program. As such, in addition to examining junior and intermediate classes as above, FSL research exploring the issue of SSEN includes research at the primary level. Pellerin (2013), for example, examined how technology could be an asset to increase inclusive practices in the early French immersion classroom. In this action research project, the researcher collaborated with 12 teachers over a two-year period. Throughout the project, Pellerin met with the teachers to offer professional development. She collected data from the teachers' use of technology, from classroom observations and from interviews with teachers. She found that the teachers' use of IPads and IPods allowed them to offer more individualized support while at the same time increasing student autonomy. This use of technology allowed teachers to work with students individually and in small groups and diversify their assessment practices to include audio and video recordings. Students in the technology enhanced FSL classes demonstrated a higher level of engagement and interest in learning to read and speak French. The technology use proved to be an effective means of increasing inclusive instruction. Moreover, teachers revealed that the professional development meetings, in which they shared their experiences with colleagues, were instrumental in encouraging the use of diverse instructional strategies.

Also at the primary level, Bournot-Trites, Lee and Séror (2003) conducted a study within the context of a parent-school partnership project developed to improve the reading proficiency of French immersion students through peer tutoring. Grade 2 and 3 students, identified as having mild learning difficulties, were selected by their teachers or resource teachers to participate in the project. These students took part in 30-minute tutoring sessions twice weekly over a period of sixteen weeks. These sessions were led by peer tutors in Grades 5 to 7 , who had been selected based on their learning skills and enthusiasm rather than for having advanced reading skills. Peer tutors received training on instructional strategies, reading strategies and on how to run a tutoring session, which entailed selecting appropriate reading material, taking session notes and completing reading assessment forms. The reading strategies taught included: choral reading, prediction, identifying words through context and vocabulary building activities. The Grade 2 and 3 students in the experimental group were twinned with students in control schools who had tested at analogous reading levels initially; these students did not take part in peer tutoring sessions. Participants were tested both for decoding and reading comprehension. The two-year study reported statistically significant positive effects of peer tutoring on reading proficiency for half of the participants and self-reported positive effects for all participants $(\mathrm{N}=70)$. The authors noted that peer tutoring is effective as a support for students with mild learning difficulties. All participants, including the peer tutors, reported more positive attitudes towards reading and greater awareness of reading difficulties.

As suggested by the above-described study, in addition to teachers supporting the inclusion of students with learning difficulties, students can also be a means of support. For instance at the junior level, Litvack, Ritchie and Shore (2011) explored the attitudes of gifted students who were in Grades 4, 5, and 6 French immersion toward students with learning disabilities. The 14 teachers and 220 student participants completed questionnaires regarding the inclusion of students with learning disabilities. The students also participated in interviews. Upon comparing the attitudes of the three groups toward students with learning difficulties shown in the questionnaires, the researchers to found no significant differences among the groups. All groups showed positive attitudes toward the inclusion of students with disabilities.

This concept of using peer and class support to promote the inclusion of SSEN is at the core of an innovative program, offered by the Calgary Board of Education (Brims, 2012). The French immersion Learning and Literacy $(\mathrm{L} \& \mathrm{~L})$ program is an intervention program for junior level students with identified literacy-related learning disabilities, where SSEN are provided with assistive technology, additional skill and strategy training, and social support. The classroom teacher and the $L \& L$ teachers, who are both well informed about the learning disabilities in the group, work together to team-teach. In addition to developing their literacy skills, reinforcing areas of strength and building self-esteem, students in the program are taught to self-advocate. They are encouraged to make brochures about themselves as learners to provide to teachers who will work with them in the future. The positive impact of the program is highlighted in such statements as: 
Having participated in the program for two years, we were very surprised with the incredible progress made and truly could not be happier with the teachers and opportunity to join the program. Our child went from being $11 / 2$ years below grade level to being at grade level and no longer requiring an IPP [Individualized Program Plans] on many reading and writing standards on the report cards (Brims, 2012, p. 38).

In addition to the research conducted at the primary and junior levels, Le Bouthillier (2013) conducted a case study of a Grade 7 student with Asperger Syndrome (AS) in French immersion. Through her review of literature on AS and through her observations of the student in her case study, Le Bouthillier suggested providing graphic organizers, using highlighters to support student identification of important information, and giving instruction and feedback on cue-cards rather than orally as a means to respond to the particular needs of students with AS during the writing process. She cites the increasing number of students in immersion who are identified as having AS as grounds for further research into understanding and accommodating their learning needs in FSL.

\subsubsection{Provision of Support in French Immersion}

The suitability of French immersion for SSEN has been an area of investigation since the program's inception (Genesee, 2007). In fact, Genesee (2004) goes as far as stating that SSEN are entitled to relevant, supportive services in order to be included in immersion. In addition to the support from FSL teachers and peers described above, instructional support for students in French immersion includes access to special education resources.

To assure appropriate access to such resources, special education support should be provided in the administration and interpretation of measurements as well as the potential ensuing interventions. Such interventions can be more complex in French immersion, given the two languages of instruction. MacCoubrey, Wade-Woolley, Klinger, and Kirby (2004) explored whether predictive tests for reading impairment and reading difficulties taken in English could predict future reading difficulties in English and French with primary early French immersion students. Using predictive discriminant analysis of the test results from Grade 1 students $(\mathrm{N}=77)$, the researchers determined that the English tests could predict future reading difficulties in English and French. MacCoubrey et al. suggested that using such measures before students are learning to read would allow for early interventions and therefore the potential avoidance of failure.

Similarly, Erdos, Genesee, Savage and Haigh (2014) examined whether English measurements could predict reading impairment and oral language difficulties in French immersion students. The researchers tested 86 French immersion students on two occasions (fall and spring) in kindergarten and on one occasion in the spring of Grade 1. From those data sets, they then determined that measures of phonological awareness, phonological access and letter-sound knowledge could identify potential reading impairment and tests of sentence repetition, phonological awareness and tense marking could predict oral language difficulties. The results suggested that measurements taken in English can predict risks for reading and oral difficulties for students in early French immersion. The authors purported that the results support the testing of students in English, as it can differentially identify reading and oral difficulties. They stated that such identification could allow not only for early intervention but also for tailoring of intervention to the particular difficulties.

Jared, Cormier, Levy, and Wade-Woolley (2011) also investigated variables that impact English and French reading skills of English-speaking French immersion students. The researchers used a battery of English tests with children from kindergarten to Grade 3 to determine that phonological awareness, grammatical ability, rapid automatized naming of letters, letter-sound knowledge and word identification skills were good predictors of reading ability. The authors posited that such tests would enable the early identification of reading difficulties so as to allow for the necessary provisions of support to be made for students with potential challenges.

In their three-year longitudinal study of individual differences in reading outcomes, Erdos, Genesee, Savage and Haigh (2011) found that knowledge of French, as measured by a receptive vocabulary test at school entry, was a significant predictor of decoding outcomes in Grade 1. They stressed that direct, explicit vocabulary instruction and listening comprehension are important components of early L2 reading programs. Results regarding the role of L1 letter-name knowledge and phonological processing as a predictor of Kindergarten students' L2 decoding and reading comprehension by the end of Grade 1 corroborated those of previous studies (e.g., Comeau et al., 1999; MacCoubrey et al., 2004; Tingley et al., 2004). The authors concluded that these combined results constitute evidence justifying the early identification of French immersion students potentially at risk for reading difficulties.

In an additional study on predictors of early literacy, Bourgoin (2014b) examined L2 reading achievement. The longitudinal study followed kindergarten students $(\mathrm{N}=83)$ through to the end of Grade $3(\mathrm{~N}=53)$, thus permitting 
examination of long-term connections between L1 and L2 literacy indicators. The Dynamic Indicators of Basic Early Literacy Skills (DIBELS) administered in fall, winter and spring of kindergarten, tested phonological awareness and decoding. In Grade 3, phonological awareness and decoding were tested using IDAPEL (the French version of DIBELS) and reading comprehension was tested using Running Records (Clay, 1993). Significant positive correlations were found between the majority of L1 literacy predictors and L2 reading outcomes. Significant positive correlations were also found between L2 predictors and L2 reading outcomes. The strongest literacy predictor was found to be alphabetic knowledge, followed by phonological knowledge. Nonsense word reading had little statistical significance in predicting future L2 reading fluency, accuracy, or comprehension. This particular finding, which Bourgoin noted concurs with that of Jared et al. (2011), relates to several features of the study that sets it apart. Unlike previous studies of relationships between L1 and L2 literacy indicators, Bourgoin's investigation presents a vision of reading ability that goes beyond the decoding of nonsense words and graded wordlists, by examining the learners' ability to create meaning from text. Contrary to findings that L1 literacy correlated to decoding skills but not to reading comprehension, L2 predictors indicated both fluency and comprehension. Bourgoin posited that this is due to the fact that most participants were already aware that reading is essentially a comprehension task when they entered the immersion program. The study concluded that students who need additional support in learning to read in the L2 can be identified using early literacy indicators, both in their L1 (administered before L2 learning) and in their L2 (administered concurrently with L2 learning).

The above-described research into the transferability of identification practices between French and English is supported by much earlier studies such as Comeau et al. (1999), who examined the transfer of phonological awareness in their longitudinal study of French immersion students $(\mathrm{N}=122)$ in Grades 1, 3 and 5. Their findings supported transfer of phonological awareness across alphabetic languages. The researchers were able to confirm their hypothesis that it is possible to apply identification of phonological awareness as the "most important concurrent and longitudinal predictor of word decoding" (p. 1) in L1 to immersion contexts.

The above identification research within the French immersion context offers opportunities to assess and identify student needs, thereby making it possible to tailor instruction to individual learners' identified needs. Wise and Chen (2010) examined the impact of one ensuing intervention. In particular, they explored the use of phonological instruction in both English and French on at-risk students' reading abilities in early French immersion. Grade 1 students $(\mathrm{N}=29)$ who were identified as being at-risk readers participated in the study -15 participants in the treatment group and 14 in the control group. The treatment group received phonological instruction in small groups delivered in English for a 10-week period. This was followed by a 10-week instructional period on French phonology for a total of twenty hours. After the treatment, the researchers used two measurements of reading outcomes to determine achievement - a French reading assessment and the reading achievement levels noted on the provincial report card. The results showed significant improvement for the treatment group and a significant difference between the treatment and control groups, with the treatment groups outperforming the control group in both the reading assessments and the report card levels. Wise and Chen concluded that at-risk readers could improve their reading skills with interventions that focus on phonological awareness. They linked the success of the interventions to the opportunity to intervene at the beginning of the students' French immersion experience. Initial intervention took place in English, with subsequent intervention continuing in French once a 10-week foundation was established.

In addition to using assessments, Bourgoin and Dicks' (2013) study suggested an additional potential area of focus for ensuing interventions. The researchers' ethnographic case study compared the acquisition of L2 literacy skills of high-performing and at-risk readers in French immersion. Unlike previous studies (e.g., MacCourbrey et al., 2004), the particular immersion program structure permitted the study of learners who had already had three years of L1 literacy instruction. All were Anglophones who had been identified as being either high-performing $(\mathrm{N}=4)$ or at-risk $(\mathrm{N}=4)$ readers based on DIBELS tests administered in English while the students were in Grade 2. Analysis of three subsequent administrations of the French version of the test (IDAPEL) the following year pointed to a positive correlation between L1 and L2 reading competency. The authors recorded a series of think-aloud reading sessions in which readers described their thoughts as they read. The think-alouds for this study focused on strategy use and revealed greater frequency and variety in the strategy use of high-performing L2 readers. In addition to contributing to the body of literature substantiating the need to identify and support at-risk readers in the early stages of L2 acquisition, Bourgoin and Dicks' findings underscore the need to promote and develop metacognitive skills among at-risk student readers. 


\section{Discussion}

This review sought to provide information to FSL instructors to better support SSEN in their FSL classrooms. In particular, in recognition of FSL teachers' stated need for information and their willingness to use information from research to inform practice where access and practical applications are provided, this review was limited to studies that offered practical instructional supports. In addition to supporting FSL teachers with information and practical support, this review gathered information from a variety of sources to support teachers who have indicated lack of time to be able to conduct such searches of academic material (Mady, 2013) as a barrier to consulting research.

Overall, our search for instructional supports for SSEN in FSL revealed a variety of supports to promote SSEN' success in FSL. Research in core and intensive French contexts revealed that instructional strategies (e.g., use of French, use of gestures, group work and modeling) enhance learning for SSEN. Research in French immersion settings showed that in-class peer support, peer tutoring, the use of technology, and instructional choices such as the use of feedback and vocabulary instruction, contribute to successful experiences in FSL for SSEN. Although the context for the research varied, we suggest the highlighted instructional suggestions are transferable from one FSL context to the next.

Unique to the French immersion context, however, is the question of identification of SSEN and the language of accompanying assessments. The research in French immersion showed that early identification of difficulties is advantageous and that such identification is possible in English. Although supported by minimal research, the ensuing interventions proved advantageous to SSEN in FSL. In addition to interventions focusing on phonological awareness, explicit attention to strategy use, influence of the L1 and metacognitive awareness were also shown to be of potential benefit. Profiting from such interventions would increase possibilities for SSEN to benefit from FSL learning opportunities. Specifically, SSEN may experience increased self-esteem, motivation and confidence. In addition to these affective benefits, SSEN may profit from enhanced strategy use, better phonological awareness, decoding skills, and heightened morphological awareness.

As researchers and educators move forward in their work to understand and address the needs of SSEN in FSL, they may do so with the knowledge that SSEN have the potential to gain L2 skills and related cognitive skills, while remaining at least on par academically with SSEN who do not study FSL (Genesee, 2007). Furthermore, SSEN who are included in FSL programs may gain increased confidence and other affective benefits associated with feeling included. Increased inclusion and related pedagogical knowledge have the potential to benefit all learners (Ontario Ministry of Education, 2015, p. 12).

\section{Acknowledgments}

We are thankful to the Ontario Ministry of Education for commissioning this literature review.

\section{References}

Arnett, K. (2003). Teacher adaptations in core French: A case study of one grade 9 class. The Canadian Modern Language Review, 60(2), 173-198. https://doi.org/10.3138/cmlr.60.2.173

Arnett, K. (2008). Exploring the use of student perspectives to inform topics in teacher education. Canadian Journal of Applied Linguistics, 11(1), 63-82.

Arnett, K. (2010). Scaffolding in a grade 8 core French classroom: An exploratory case study. The Canadian Modern Language Review, 66(4), 557-582. https://doi.org/10.3138/cmlr.66.4.557

Arnett, K. (2013). The genesis and perpetuation of exemptions and transfers from French Second Language programs for students with diverse learning needs: A preliminary examination and their link to inclusion. In K. Arnett, \& C. Mady (Eds.), Minority populations in Canadian second language education (pp. 103-117). Bristol, UK: Multilingual Matters.

Bourgoin, R. (2014a). Inclusionary practices in French immersion: A need to link research to practice. Canadian Journal for New Scholars in Education, 5(1), 1-11.

Bourgoin, R. (2014b). The Predictive Effects of L1 and L2 Early Literacy Indicators on Reading in French Immersion. Canadian Modern Language Review, 70(3), 355-380. https://doi.org/10.3138/cmlr.2346

Bourgoin, R., \& Dicks, J. (2013). Reading Without Borders: L1 and L2 Students Experiences in English and French Immersion Programs. Bristol, UK: Multilingual Matters. 
Bournot-Trites, M., Lee, E., \& Séror, J. (2003). Tutorat par les pairs en lecture: Une collaboration parents-école en milieu d'immersion française. Revue des sciences de l'éducation, 29(1), 195-210. https://doi.org/10.7202/009498ar

Brims, S. (2012, June). Meeting student needs in French immersion: Learning and literacy programming. In Proceedings of the Canadian Parents for French Roundtable on Academically Challenged Students in French Second Language Programs (pp. 34-38). Ottawa, ON: Canadian Parents for French.

Bruck, M. (1978). The suitability of early French immersion for the language disabled child. The Canadian Modern Language Review, 34(5), 884-887. https://doi.org/10.2307/1494685

Canadian Association of Second Language Teachers. (2004). Status of Core French Teachers and Their Programs Executive Summary, Focus Group Sessions. Retrieved from https://www.caslt.org/pdf/FocusGrpExecSummary.pdf

Carr, W. (2007). Teaching core French in British Columbia: Teachers' perspectives. Vancouver, BC: British Columbia Association of Teachers of Modern Languages.

Comeau, L., Cormier, P., Grandmaison, E., \& LaCroix, D. (1999). A Longitudinal Study of Phonological Processing Skills in Children Learning to Read in a Second Language. Journal of Educational Psychology, 91(1), 29-43. https://doi.org/10.1037/0022-0663.91.1.29

Corbin, J., \& Strauss, A. (2008). Basics of qualitative research: Techniques and procedures for developing grounded theory (3rd ed.). Thousand Oaks, CA: Sage. https://doi.org/10.4135/9781452230153

Erdos, C., Genesee, F., Savage, R., \& Haigh. C. (2011). Individual differences in second language reading outcomes. International Journal of Bilingualism, 15(1), 3-25. https://doi.org/10.1177/1367006910371022

Erdos, C., Genesee, F., Savage, R., \& Haigh, C. (2014). Predicting risk for oral and written language learning difficulties in students' education in a second language. Applied Psycholinguistics, 35, 371-398. https://doi.org/10.1017/S0142716412000422

Fereday, J., \& Muir-Cochrane, E. (2006). Demonstrating rigor using thematic analysis: A hyrbrid approach of inductive and deductive coding and theme development. International Journal of Qualitative Methods, 5(1), $80-92$.

Genesee, F. (2004). What do we know about bilingual education for majority language students. In T. K. Bhatia, \& W. Ritchie (Eds.), Handbook of Bilingualism and Multiculturalism (pp. 547-576). Malden, MA: Blackwell.

Genesee, F. (2007). French immersion and at-risk students: A review of research evidence. The Canadian Modern Language Review, 63(5), 654-687. https://doi.org/10.3138/cmlr.63.5.655

Jared, D., Cormier, P., Levy, B., \& Wade-Woolley, L. (2011). Early predictors of biliteracy development in children in French immersion: A 4-year longitudinal study. Journal of Education Psychology, 103(1), 119-139. https://doi.org/10.1037/a0021284

Joy, R., \& Murphy, E. (2012). The inclusion of children with special education needs in an intensive French as a second language program: From theory to practice. Canadian Journal of Education, 25(1), 102-119.

Labuschagne, A. (n.d.). Qualitative research: Airy fairy or fundamental? The Qualitative Report, 8(1), Article 7. Retrieved from http://www.nova.edu/ssss/QR/QR8-1/labuschagne.html

Lapkin, S., MacFarlane, A., \& Vandergrift, L. (2006). Teaching French in Canada: FSL teachers' perspectives. Ottawa, ON: Canadian Teachers' Federation.

Le Bouthillier, J. (2013). The writing processes of a Grade 7 French immersion student with Asperger Syndrome. Bristol, UK: Multilingual Matters.

Litvack, M., Ritchie, K., \& Shore, B. (2011). High- and average-achieving students' perceptions of disabilities and of students with disabilities in inclusive classrooms. Council for Exceptional Children, 77(4), 474-487.

MacCoubrey, S., Wade-Woolley, L., Klinger, D., \& Kirby, J. (2004). Early identification of at-risk L2 readers. The Canadian Modern Language Review, 61(1), 11-28. https://doi.org/10.3138/cmlr.61.1.11

Mady, C. (2012). Second language research and teaching: Bridging the gap. Babel, 47(2), 30-37.

Mady, C. (2013). Reducing the gap between educational research and second language teachers' knowledge. Evidence and Policy, 9(2), 1-22. http://doi.org/10.1332/174426413X662509 
Mannavarayan, J. M. (2002). The French immersion debate: French for all or all for French? Calgary, Alberta, Canada: Detselig Enterprises.

Mollica, A., Philips, G., \& Smith, M. (2005). Teaching and learning French as a second language: Core French in the elementary schools in Ontario. Report prepared for the Ontario Modern Language Teachers' Association.

Netten, J., \& Germain, C. (2009). The future of intensive French in Canada. The Canadian Modern Language Review, 65(5), 757-786. https://doi.org/10.3138/cmlr.65.5.757

Ontario Ministry of Education. (2015). Including students with special education needs in French as a second language education programs. Toronto, ON: Author.

Pellerin, M. (2013) E-inclusion in early French immersion classrooms: Using digital technologies to support inclusive practices that meet the needs of all learners. Canadian Journal of Education, 36(1), 44-70.

Tingley, P., Dore, K., Lopez, A., Parsons, H., Campbell, E., Bird, E., \& Cleave, P. (2004). A Comparison of Phonological Awareness Skills in Early French Immersion and English Children. Journal of Psychological Research, 33(3), 263-287. https://doi.org/10.1023/B:JOPR.0000027965.77686.1b

Trites, R. L., \& Price, M. A. (1976). Learning disabilities found in association with French immersion programming. Ottawa, ON: University of Ottawa Press.

Trites, R. L., \& Price, M. A. (1977). Learning disabilities found in association with French immersion programming: A cross-validation. Ottawa, ON: University of Ottawa Press.

Wise, N. (2011). Access to special education for exceptional students in French immersion programs: An equity issue. The Canadian Journal of Applied Linguistics, 14(2), 177-193.

Wise, N., \& Chen, X. (2010). At-risk readers in French immersion: Early identification and early intervention. Canadian Journal of Applied Linguistics, 13(2), 128-149.

\section{Notes}

Note 1. For this paper, students with special education needs refers to students who have been formally or informally identified by educators or specialists as in need of special education support (i.e., accommodations and/or modifications to curriculum).

Note 2. Core French is a program in which French is taught as a subject for one period each day or several periods each week, approximately 40 minutes per day in elementary school or one period per day for one semester in a semestered secondary school. French immersion is a program where students study the language and subjects delivered in French for a minimum 50\% of their instructional time. Intensive French is a program in which French is taught intensively for most of the day during five months in Grade 5 or 6 , followed by a schedule resembling core French for the rest of the initial year and subsequent years.

Note 3. The Intensive French program was launched in 1998.

\section{Copyrights}

Copyright for this article is retained by the author(s), with first publication rights granted to the journal.

This is an open-access article distributed under the terms and conditions of the Creative Commons Attribution license (http://creativecommons.org/licenses/by/4.0/). 